\title{
OCCURRENCE AND DIVERSITY OF Ralstonia solanacearum POPULATIONS IN BRAZIL
}

\section{OCORRENCIA E DIVERSIDADE DE POPULAÇÕES DE Ralstonia solanacearum NO BRASIL}

\author{
Tâmara Prado de MORAIS ${ }^{1}$; Carlos Alberto LOPES $^{2}$; Nilvanira Donizete TEBALDI ${ }^{3}$; \\ José Magno Queiroz LUZ ${ }^{3}$ \\ 1. PhD. Student, Institute of Agricultural Sciences, Universidade Federal de Uberlândia-UFU, Uberlândia, MG, Brazil; 2. Researcher, \\ Embrapa Hortaliças, Brasília, DF, Brazil; 3. Professor, PhD., Universidade Federal de Uberlândia, UFU, Uberlândia, MG, Brazil. \\ nilvanira@iciag.ufu.br; jmagno@umuarama.ufu.br
}

\begin{abstract}
Ralstonia solanacearum is a gram-negative soil-borne bacterium capable of infection of hundreds of vegetable species over more than 50 botanical families, causing bacterial wilt, except for bananas, when the disease is called Moko. It deserves special attention, from all other plant pathogenic bacteria, for its high phenotypic and genotypic plasticity, a characteristic that makes disease control extremely difficult. In this context, frequent and necessary surveys are conduct in the attempt of characterizing the prevailing strains of $R$. solanacearum in each region where the disease has been reported. However, knowledge about occurrence and diversity of $R$. solanacearum in Brazil is fragmented and in some cases, based on inconclusive studies with few strains, little representative of a given region. The need to obtain a greater picture guided this review. The occurrence of this bacterium in Brazilian States and the possible causes for its dissemination are presented, with emphasis on studies of genetic variability of populations of $R$. solanacearum in the country. The compiled results report a wide distribution of the bacterium in Brazil and great variability of its populations among locations. Partly due to the difficulty of detecting small titer of bacteria in samples, paucity of information about the origin of inoculum in certain regions is observed, as well as the need for detecting the presence of the pathogen in asymptomatic plants, potato tubers with latent infections, soil, and water, which are the major causes of bacterial dissemination into areas without any disease history.
\end{abstract}

KEYWORDS: Bacterial wilt. Phylotypes. Genetic diversity. Phenotypic characterization.

\section{INTRODUCTION}

Bacterial wilt, caused by Ralstonia solanacearum [(SMITH, 1896) YABUUCHI et al., 1996], was apparently first observed in tobacco plants in Japan, at the end of the $17^{\text {th }}$ century (KELMAN, 1953). Since then, several reports suggest the introduction of the bacterium into new areas, or the existence of different centers of origin for this pathogen, besides those about the occupation of some soil, climate, and new host niches around the world due to the evolution of the bacterium. In Brazil, the disease was first reported by Von Parseval, in 1922, in tobacco crops in the State of Rio Grande do Sul (TAKATSU; LOPES, 1997). Detailed information about the disease history and pathogen dissemination around the world can be found in Lopes (2005).

The pathogen causing bacterial wilt was first described as Bacillus solanacearum by Smith (1896). Subsequently, it was classified as Bacterium solanacearum (CHESTER, 1898), Pseudomonas solanacearum [(SMITH, 1896) SMITH, 1914], Phytomonas solanaceara [(SMITH, 1896) BERGEY et al., 1923], and Burkholderia solanacearum [(SMITH, 1896) YABUUCHI et al.,
1992]. Three years after the last classification, the species was moved to the present genus Ralstonia [(SMITH, 1896) comb. nov. YABUUCHI et al., 1995] and its validation published in 1996 (YABUUCHI et al., 1996).

Ralstonia solanacearum is a vascular pathogen and is widely distributed in tropical, subtropical, and temperate climate regions affecting several crops, including monocots as well as dicots (BUDDENHAGEN; KELMAN, 1964; HAYWARD, 1994). In Brazil, the most affected species are solanaceae such as potato, tomato, bell pepper, eggplant, tobacco, and gilo, but also include banana, heliconia, eucalypt, and castor beans, among others (MALAVOLTA JÚNIOR et al., 2008). Such wide geographical distribution and host range can be attributed to the species genetic heterogeneity, including divergent strains with more than 30\% dissimilarity (REMENANT et al., 2010), which confers it the definition of a species complex (FEGAN; PRIOR, 2005).

Ralstonia solanacearum can be disseminated by soil adhered to machinery and implements, by water, and propagation materials such as potato tubers, rhizomes, and seedlings. Except for some strains from banana that can be 
transmitted by insects visiting flowers, plants are usually infected from the root system. By penetrating through wounds, which can be minimal such as those caused by the emergence of secondary roots, the bacteria quickly colonize the xylem vessels. Colonized vessels become inoperative for water transport from roots to shoots resulting in brown discoloration of vascular tissues, stunting, wilt, and death of the infected plant.

Control of bacterial wilt is difficult, since the pathogen can survive for many years in infested soil and weeds. Plant breeding for resistant cultivars, considered as the best control strategy for the bacteriosis, is troublesome due to the lack of good resistance sources among the vegetable species and the genetic diversity of the pathogen (LOPES, 2005; REMENANT et al., 2010).

In Brazil, bacterial wilt has been reported in all States and is responsible for expressive decline in yield of agriculturally important crops and the condemnation of growing fields, especially those dedicated to the certification of potato seeds. Infested areas become useless for growing susceptible species such as potato, tomato, bell pepper, and banana.

Due to the economic losses caused by $R$. solanacearum, knowledge about its regional occurrence and variability is mandatory. Presently, great emphasis has been given to population genetic studies of this bacterium, which are fundamental for the understanding of the specific resistance of cultivars to certain locations and on the development of control strategies.
Until now, knowledge about occurrence and diversity of $R$. solanacearum in Brazilian regions was fragmented and in some cases, based only on the inclusion of few strains, often not representing the local variability. Thus, this review presents the bacterium distribution in the country, relating it to economically important vegetable species and discussing possible causes of its dissemination. Studies about the genetic variability of $R$. solanacearum and the discrimination of Brazilian strains according to the current classification scheme for this bacterium are also presented.

\section{REVIEW}

\section{Ralstonia solanacearum races and biovars in Brazil}

Presently, Ralstonia solanacearum variability is represented by five pathogenic races (as a function of the host range) and six biovars (based on their ability to metabolize sugars and alcohols) (BUDDENHAGEN; SEQUEIRA; KELMAN, 1962; BUDDENHAGEN, 1986; HAYWARD, 1991; HAYWARD, 1994; HAYWARD; FEGAN, 2004). In Brazil, surveys done in several geographical regions indicated the existence of races 1,2 , and 3, associated to several agriculturally important crops and some ornamental plants. Biovar 1 has been reported in all regions of the country, while biovar 2 predominates in mild climates (South, Southeast and Middle-West), and biovar 3 in the North and Northeast. Biovars 4 and 5 have not been reported in the country (Table 1 ).

Table 1. Occurrence of Ralstonia solanacearum biovars and races in Brazil.

\begin{tabular}{|c|c|c|c|c|}
\hline Host & Biovar & Race & State/Region & Reference \\
\hline Potato & $\begin{array}{c}1 \\
2 \\
2 \mathrm{~T}\end{array}$ & $\begin{array}{l}1 \\
3\end{array}$ & $\begin{array}{l}\text { RS, PR, SC, } \\
\text { Middle-West }\end{array}$ & $\begin{array}{l}\text { LOPES; NAZARENO; FURIATTI, 1993; FRENCH et al., } \\
\text { 1993; MACIEL et al., 2001; MACIEL; DUARTE; } \\
\text { SILVEIRA, 2004; SILVEIRA; DUARTE; MORAES, 2002; } \\
\text { SILVEIRA et al., 2005; SANTANA et al., } 2012\end{array}$ \\
\hline Tomato & $\begin{array}{c}1 \\
2 \mathrm{~T} \\
3\end{array}$ & 1 & $\begin{array}{c}\text { AM, RS, TO, } \\
\text { RR, DF }\end{array}$ & $\begin{array}{l}\text { COELHO NETTO et al., 2003, 2004; SILVEIRA et al., 2006; } \\
\text { COSTA; FERREIRA; LOPES, 2007; LIMA NETO et al., } \\
\text { 2009; LIMA et al., } 2010\end{array}$ \\
\hline Eggplant & 1 & 1 & $\mathrm{RS}, \mathrm{AM}$ & COELHO NETTO et al., 2004; SILVEIRA et al., 2006 \\
\hline Eucalypt & $\begin{array}{c}1 \\
2 \mathrm{~T}\end{array}$ & 3 & $\begin{array}{l}\text { ES, SC, MA, } \\
\text { MG, BA, PA, } \\
\text { GO, AM }\end{array}$ & $\begin{array}{l}\text { SUDO; OLIVEIRA; PEREIRA, 1983; DIANESE; } \\
\text { TAKATSU, 1985; DRISTIG; DIANESE; TAKATSU, 1988; } \\
\text { ROBBS; CRUZ; RODRIGUES NETO, 1988; ALFENAS et } \\
\text { al., 2006; AUER; SANTOS; RODRIGUES NETO, 2008; } \\
\text { MAFIA et al., 2012; MARQUES et al., 2012; FONSECA et } \\
\text { al., } 2014\end{array}$ \\
\hline Geranium & 2 & 3 & SP & ALMEIDA et al., 2003 \\
\hline Bell pepper & $\begin{array}{l}1 \\
3\end{array}$ & 1 & $\begin{array}{l}\text { AM, BA, ES, } \\
\text { MA, PB, PE, } \\
\text { PR, RJ, RO, } \\
\text { RR, SP }\end{array}$ & $\begin{array}{c}\text { MARTINS; TAKATSU; REIFSCHNEIDER, 1988; } \\
\text { MARIANO; CABRAL; SILVA, 1988, MARIANO et al., } \\
\text { 1989; COELHO NETTO et al., 2004; LOPES; CARVALHO; } \\
\text { BOITEUX, 2005; MALAVOLTA JÚNIOR et al., 2008; } \\
\text { GARCIA et al., } 2013\end{array}$ \\
\hline Capsicum chinense & 3 & 1 & $\mathrm{AM}$ & COELHO NETTO et al., 2004 \\
\hline
\end{tabular}




\begin{tabular}{|c|c|c|c|c|}
\hline Jacq. & & & & \\
\hline $\begin{array}{l}\text { Capsicum } \\
\text { frutensens } \mathrm{L} .\end{array}$ & 3 & 1 & AM & COELHO NETTO et al., 2004 \\
\hline Gilo & $\begin{array}{c}2 \mathrm{~T} \\
3\end{array}$ & 1 & $\mathrm{TO}, \mathrm{AM}$ & COELHO NETTO et al., 2004; LIMA NETO et al., 2009 \\
\hline Tobacco & $\begin{array}{l}1 \\
3\end{array}$ & 1 & $\begin{array}{l}\mathrm{RS}, \mathrm{BA}, \mathrm{PR} \\
\mathrm{SC}, \mathrm{PB}, \mathrm{PE}\end{array}$ & $\begin{array}{l}\text { DUARTE; DALBOSCO; TASSA, 2003; SILVEIRA et al., } \\
\text { 2006; VIANA; BERGER; DUARTE, } 2012\end{array}$ \\
\hline Solanaceae & $2 \mathrm{~T}$ & 3 & $\begin{array}{l}\mathrm{GO}, \mathrm{DF}, \mathrm{MG} \\
\mathrm{BA}, \mathrm{PR} \\
\end{array}$ & SANTANA et al., 2012 \\
\hline Heliconia & 1 & 2 & $\begin{array}{l}\text { AP, PA, AM, } \\
\text { PE, SE, RO, } \\
\text { RR, DF }\end{array}$ & $\begin{array}{c}\text { ASSIS et al., 2005; ZOCOLLI et al., 2009; RODRIGUES et } \\
\text { al., 2011; CONABAN, } 2012\end{array}$ \\
\hline Banana & 1 & 2 & $\begin{array}{l}\text { AP, BA, PA, } \\
\text { AM, PE, SE, } \\
\text { RO, RR }\end{array}$ & $\begin{array}{l}\text { TOKESHI; DUARTE, 1976; FREIRE; CARDOSO; VIANA, } \\
\text { 2003; VIEIRA JÚNIOR et al., 2010; TALAMINI et al., 2010; } \\
\text { RODRIGUES et al., 2011; CONABAN, } 2012\end{array}$ \\
\hline Castor bean & ND & ND & Northeast, PB & $\begin{array}{l}\text { MARIANO; SILVEIRA; MICHEREFF, 1998; SOARES et } \\
\text { al., } 2010\end{array}$ \\
\hline Chicory & 1 & & PA & COSTA; FERREIRA; LOPES, 2007 \\
\hline Bean & & 1 & RJ & AKIBA et al., 1980 \\
\hline Cucumber & $\begin{array}{l}1 \\
3\end{array}$ & & AM & PARENTE; TAKATSU; LOPES, 1988 \\
\hline Passion fruit & ND & ND & PA & LOPES et al., 1999 \\
\hline Squash & 1 & 1 & SP & SINIGAGLIA et al., 2001 \\
\hline Olive tree & 1 & ND & MG & TEBALDI et al., 2014 \\
\hline
\end{tabular}

ND: not determined.

Race 1 , accommodating biovars 1 and 3, is frequently found in the North Region reinforcing indications that $R$. solanacearum has its center of origin in the Amazon (HAYWARD, 1991). Despite that, this race has affected many tomato, potato, bell pepper, gilo, and tobacco crops in all Brazilian regions (MARTINS; TAKATSU; REIFSCHNEIDER, 1988; COELHO NETTO et al., 2003; DUARTE; DALBOSCO; TASSA, 2003; LOPES; CARVALHO; BOITEUX, 2005; MALAVOLTA JÚNIOR et al., 2008; LIMA NETO et al., 2009; LIMA et al., 2010).

Dissemination of race 1 throughout the country could be due to the introduction of contaminated seedlings coming from other regions of the country or from abroad. After the cultivation of diseased plants, the soil also becomes an inoculum source infecting subsequent crops, especially those of solanaceae. However, Felix et al. (2012) stated that in soils where race 1 is not native, its survival in the lack of hosts is limited to up to 11 weeks. Those authors evaluated 10 different soil types although a single bacterial strain (A1-9 ${ }^{\text {Rif }}$ ), which makes difficult to generalize in face of the variability within race 1 and the efficacy of Ralstonia populations in extracting nutrients from the soil for their survival in the absence of the host.

In the Middle-West, R1Bv1 (Race 1, Biovar 1) was reported in solanaceae by Takatsu, Silva and Reifschneider in 1984. Subsequently, its occurrence was reported in potato in South of Brazil, although in lower frequency than R3Bv2 (LOPES; NAZARENO; FURIATTI, 1993; MACIEL et al., 2001; SILVEIRA; DUARTE; MORAES，2002; SILVEIRA et al., 2005). Moreover, under special conditions of moisture and temperature, it has caused significant losses in commercial eucalypt nurseries in the States of Espírito Santo, Santa Catarina, Maranhão, Minas Gerais, Bahia, Pará, and Goiás (ALFENAS et al., 2006; AUER; SANTOS; RODRIGUES NETO, 2008). Recent observations of bacterial wilt in eucalypts indicate the existence of potential primary inoculum sources in the formation and management of clonal mini-gardens. The hypotheses include the transmission of the pathogen through seedlings with latent or quiescent infections, through rooting substrate, irrigation water, or even through weeds naturally present in the nurseries (MAFIA et al., 2012).

$\mathrm{R} 3 \mathrm{Bv} 2$ is known as the "potato-race" and, differently from race 1 , presents a restricted number of host species. It is most commonly found, with no exclusivity, in crops in the South and Southeast, where most of the potato is grown in country (FRENCH et al., 1993; LOPES; NAZARENO; FURIATTI, 1993; MACIEL et al., 2001; SILVEIRA; DUARTE; MORAES, 2002). Besides affecting potato crops, this race was found associated to geranium (Pelargonium zonale) in the State of São Paulo (ALMEIDA et al., 2003). The occurrence of the bacterium in this ornamental plant is worrisome since Brazil exports geranium 
seedlings to several countries (ROSSATO, 2012). Although the source of contamination has not been determined, it could be associated to the substrate or to irrigation water, and the distribution of infected material could have been from a nursery or flower grower. Quarantine measures should be adopted and soil and irrigation systems inspected to avoid the exchange in contaminated plants and to prevent the dissemination of the pathogen to other areas, including those directed for potato production.

The occurrence of a given $R$. solanacearum race or biovar in a region may not be exclusive. Trials done in Rio Grande do Sul (RS), for instance, between 1997 and 1999, characterized 94\% and 6\% of $R$. solanacearum isolates as $\mathrm{R} 3 \mathrm{Bv} 2$ and $\mathrm{R} 1 \mathrm{Bv} 1$, respectively, in different potato cultivars and planting seasons (MACIEL et al., 2001; SILVEIRA; DUARTE; MORAES, 2002). High frequency of R3Bv2 was expected and confirms the hypothesis of prevalence of this biovar in that State, probably due to milder temperatures $\left(14\right.$ to $\left.22^{\circ} \mathrm{C}\right)$ during the major growing season. In turn, the occurrence of $\mathrm{R} 1 \mathrm{Bv} 1$ in spring crops indicates that late plantings are less favorable to that biovar. However, in tomato, eggplant, and tobacco grown in the same State, the predominance of R1Bv1 was identified (SILVEIRA et al., 2006). These results demonstrate that climate and soil conditions in RS allow the occurrence of both biovars, with the predominance of one of them determined by the host plant and planting season.

In the South of Brazil, the introduction of R1Bv1 strains through contaminated seed-potato and the subsequent increase of its population in the soil could explain its incidence. Thus, despite R1Bv1, apparently, having less ability to persist as a latent infection in tubers than $\mathrm{R} 3 \mathrm{Bv} 2$, it can be transmitted by contaminated propagation material and become prevalent in regions or planting seasons with higher temperatures.

Biovar 2 Tropical (2T), also known as N2, metabolically more versatile than biovar 2 Andine (2A), has been occasionally found in Brazil. This biovar was isolated from areas planted for the first time with solanaceae in the Amazon region, after the forest was felled, suggesting the presence of a yet non-identified native host for $R$. solanacearum in the forest (COELHO NETTO et al., 2004). Biovar 2T occurs in low altitude tropical climate regions and seems to have the Amazon region as its center or origin, presenting lower soil survival than biovars 1 or 3 (COELHO NETTO et al., 2004). In Brazil, besides the Amazon, this biovar has been found in Distrito Federal, Goiás, Minas Gerais, Bahia, and Paraná, infecting solanaceae
(SANTANA et al., 2012). Recently, Marques et al. (2012) described and characterized R3Bv2T in Eucalyptus urophylla $\mathrm{x} E$. grandis forests in Alexânia county- GO. Infer how this biovar was disseminated to other Brazilian States is audacious, although some possibilities can be considered. The first one would be the introduction of contaminated propagation material from Amazon areas with history of bacterial wilt. The second one would be the natural occurrence of this pathogen in soils of these States in which, in the presence of host plants and favorable climate conditions, the disease occurred. Finally, it could be that some strains, previously described as biovar 2, are, in fact, biovar 2T. This hypothesis is based on the lack of trealose test in some published reports, since the use of this carbohydrate for biovar identification is not part of the usual protocol.

The studies mentioned above confirm the high adaptability, versatility, and host range of $R$. solanacearum, warning about possible foci of bacterial wilt in locations where disease had not occurred previously and in species, until then, not considered as hosts. Among "non-traditional" host plants reported in Brazil are the common bean (AKIBA et al., 1980), eucalypt (DRISTIG; DIANESE; TAKATSU, 1988), cucumber (PARENTE; TAKATSU; LOPES, 1988), passion fruit (LOPES et al., 1999), squash (SINIGAGLIA et al., 2001), soybean, peas (BRINGEL; TAKATSU; UESUGI, 2001), and olive trees (TEBALDI et al., 2014), besides several weeds (MALAVOLTA JÚNIOR et al., 2008). Coffee was also included in this list under artificial inoculation conditions (LOPES; ROSSATO; BOITEUX, 2009).

Race 2 of $R$. solanacearum causes the disease known as the Banana's Moko, first reported in Brazil by Tokeshi and Duarte in 1976 at the Federal Territory of Amapá (now State of Pará). Since then, this race was disseminated to some States of the North and Northeast region (FREIRE; CARDOSO; VIANA, 2003; COELHO NETTO et al., 2004; ANDRADE et al., 2009). Race 2 is considered as a present quarantine pest (A2), occurring in the States of Amapá, Amazonas, Pará, Rondônia, Roraima, and Sergipe, and is restricted only to banana (Musa spp.) and Heliconia spp. (CONABAN, 2012; MAPA, 2013). Survival of the bacteria in dryland cropping areas, in contrast to floodplains of the Amazon, in the lack of the host and during the dry season, is two months long, and four months in the rainy season (CONABAN, 2012), highlighting that soil moisture is fundamental for its survival. Planting material has an important 
role in the dissemination of Moko disease, both for short and long range spread.

Surveys done in the the State of Rondônia between 2007 and 2010 showed the occurrence of Moko in several counties (VIEIRA JÚNIOR et al., 2010). However, according to these authors, there was a reduction in disease dissemination within the State in comparison with the surveys of 2004 and 2007 (first semester). Similarly, Talamini et al. (2010) observed that the disease is decreasing in Sergipe, indicating a satisfactory quarantine control. In contrast, the bacterium (R2Bv1) was reported in heliconia and ornamental Musa sp. in Distrito Federal (ZOCCOLI; TOMITA; UESUGI, 2009). It is presumed that the introduction of contaminated seedlings, mostly from the North of Brazil, is the inoculum source.

A study done by Rodrigues et al. (2011) revealed that strains isolated from Musa or Heliconia (R2Bv1) are able to cause wilt symptoms in Strelitzia. This result indicates the pathogenic potential of the bacterium for this plant species or, at least, that Strelitzia seedlings can be used as test plants for the presumptive diagnosis of Moko disease in banana.

Castor bean plants (Ricinus communis) were found, in 2009, with wilt symptoms and dieback in an experimental area of the Universidade Federal da Paraíba. The causal agent was identified as $R$. solanacearum (SOARES et al., 2010). This was the first report of this disease in the micro-region of Areia/PB. Previously, the bacterium had been reported in castor bean by Mariano, Silveira and Michereff in 1998. Although the studies do not report the biovar to which the strains belong, they are supposed to be Bv3, commonly found in the North and Northeast regions of the country.

As to the occurrence of bacterial wilt in ornamental plants in Brazil, the first report was done by Gonçalves (1937) in Dahlia sp. Since then, the disease was described in 24 ornamental host plants, including economically important species such as begonia, geranium, chrysanthemum, and heliconia (ALMEIDA et al., 2003; MALAVOLTA JÚNIOR et al., 2008; ZOCCOLI; TOMITA; UESUGI, 2009). Importation of different flower varieties with latent infection could be the cause for bacterium dissemination in ornamental plants.

\section{Genetic diversity of Ralstonia solanacearum in Brazil}

Despite its common use, the previously mentioned $R$. solanacearum classification into races and biovars has the inconvenience of inconsistency since it is based on phenotypical characteristics. The advances in molecular biology and genome sequencing of strain GMI1000 (SALANOUBAT et al., 2002) made possible to genotypically characterize the bacterium and study its variability. In this context, a new hierarchical classification scheme was proposed, with four taxonomic levels: species, phylotype, sequevar and clone (FEGAN; PRIOR, 2005).

Among the techniques used for molecular characterization of $R$. solanacearum populations, polymerase chain reaction (PCR) takes prominence. Several PCR protocols and specific primers were designed for detection or identification of the species and for phylotyping (Table 2) (SEAL et al., 1993; ELPHINSTONE et al., 1996; OPINA et al., 1997; FEGAN et al., 1998; BOUDAZIN et al., 1999; PASTRIK; MAISS, 2000; POUSSIER; LUISETTI, 2000; WELLER et al., 2000). Classification into phylotypes is done by PCR Multiplex with the Nmult series primers (based on ITS region) and the classification into sequevar by partially sequencing gene $e g l$ (encoding the enzyme endoglucanase). Presently, four phylotypes and 51 sequevares of $R$. solanacearum are described (XU et al., 2009; FONSECA et al., 2014). Analysis of genetic diversity can be conducted based on repetitive sequences (rep-PCR), comprised by the elements BOX, ERIC, and REP, by randomly amplified DNA (RAPD), by amplification of restriction fragments (AFLP), repeated simple sequences (SSR) and by polymorphisms based on restriction fragment size (RFLP) (JAUNET; WANG, 1999; POUSSIER; VANDEWALLE; LUISETTI, 1999; COENYE; VANDAMME, 2003; YU et al., 2003; KUMAR; SARMA; ANANDARAJ, 2004; SILVEIRA et al., 2005; COSTA; FERREIRA; LOPES, 2007; IVEY et al., 2007).

Silveira et al. (2005) investigated the genetic variability of $R$. solanacearum strains obtained from different potato producing areas in Rio Grande do Sul, using RAPD and repetitive sequences, differentiating biovars1 and 2 by ERIC and BOX-PCR. In this case, only BOX-PCR could confirm the variability within strains of R1Bv1. The authors concluded that RAPD (using the primer oligonucleotide OPO-10 (5'TCA GAG CGC C3') clearly demonstrated the separation of $R$. solanacearum biovars, proving that the profiles were characteristic of the regions where the strains were obtained, and that local variability was small. However, it is important to note that the ability of RAPD in detecting polymorphisms depends on the selection of primer oligonucleotides that will reveal 
greater variability among and within strains of the biovar being studied.

Table 2. Primers used for molecular analysis of Ralstonia solanacearum.

\begin{tabular}{|c|c|c|c|}
\hline Objective & Oligonucleotides & Amplicon (bp) & Reference \\
\hline Identification & $\begin{array}{l}\text { OLI1 - 5'GGGGGTAGCTTGCTACCTGCC3' } \\
\text { Y2 - 5'CCCACTGCTGCCTCCCGTAGGAGT3' }\end{array}$ & 287 & $\begin{array}{l}\text { SEAL et al., } \\
1993\end{array}$ \\
\hline & $\begin{array}{l}759 \text { - 5'GTCGCCGTCAACTCACTTTCC3' } \\
760 \text { - 5'GTCGCCGTCAGCAATGCGGAATCG3' }\end{array}$ & 280 & $\begin{array}{l}\text { OPINA et al., } \\
1997\end{array}$ \\
\hline Phylotype & $\begin{array}{ll}\text { I } & \text { Nmult:21:1F - 5'CGTTGATGAGGCGCGCAATTT3' } \\
\text { II } & \text { Nmult:21:2F - 5'AAGTTATGGACGGTGGAAGTC3' } \\
\text { III } & \text { Nmult23:AF - 5'ATTACS }{ }^{*} \text { AGAGCAATCGAAAGATT3' } \\
\text { IV } & \text { Nmult:22:Inf - 5'ATTGCCAAGACGAGAGAAGTA3' } \\
& \text { Nmult22:RR - 5'TCGCTTGACCCTATAACGAGTA3' }\end{array}$ & $\begin{array}{c}144 \\
372 \\
91 \\
213 \\
-\end{array}$ & $\begin{array}{c}\text { FEGAN; } \\
\text { PRIOR, } 2005\end{array}$ \\
\hline Sequevar & $\begin{array}{l}\text { Endo-F - 5'ATGCATGCCGCTGGTCGCCGC3' } \\
\text { Endo-R - 5'GCGTTGCCCGGCACGAACACC3' }\end{array}$ & 720 & JI et al., 2007 \\
\hline
\end{tabular}

While the population of $R$. solanacearum in Rio Grande do Sul was quite homogeneous (SILVEIRA et al., 2005), bacterial strains from the Amazon region presented high degree of polymorphism by BOX-PCR, with no correlation among genome profiles and source host, biovar, ecosystem or collection location (COSTA; FERREIRA; LOPES, 2007).

Several studies identified phylotypes of Brazilian strains of $R$. solanacearum (FEGAN; PRIOR, 2005; VILLA et al., 2005; PEREZ et al., 2008; GUIDOT et al., 2009; CELLIER; PRIOR, 2010; LEBEAU et al., 2011). In contrast, classification into sequevars has been explored only recently. Strains of R3Bv2, obtained from several potato producing regions in Brazil, were classified as biovars $2 \mathrm{~A}$ and $2 \mathrm{~T}$, phylotype II and, mostly, sequevar 1 (SANTANA et al., 2012). Such genetic uniformity makes easy the development of resistant cultivars and of pathogen detection methods.

One hundred and twenty strains from tobacco (Nicotiana tabacum L.), collected in 13 counties of Paraná, 24 of Santa Catarina, 13 of Rio Grande do Sul, one of Paraíba, and two of Pernambuco, were characterized into biovar, phylotype and by genetic diversity using the repetitive sequences BOX, ERIC, and REP (repPCR) (VIANA; BERGER; DUARTE, 2012). All studied strains belonged to R1Bv1 and phylotype II, corroborating the information presented in this review about the prevalence of this race/biovar in the South of Brazil, except when associated with potato crops. Although those authors found homogeneity in biovar and phylotype, the results of rep-PCR separated the strains into six groups, with maximum similarity of $61 \%$.
A research done by Santiago, Lopes and Mizubuti (2012), with $120 R$. solanacearum strains (from 19 Brazilian States and 12 host species), classified them as biovar $1(42.5 \%), 2(45 \%)$, and 3 $(12.5 \%)$. Biovar determination was done by biochemical tests. Moreover, the strains were grouped into phylotype II (95.8\%) and phylotype I (4.2\%, all from the North of the country). Sequencing the gene $e g l$ identified sequevars 1, 4A, $5,6,18$, and 36 .

Classification into sequevar is not always possible. For instance, from $33 R$. solanacearum strains collected from several hosts (19 strains from race 2, 14 from race 1 , and 15 strains associated to banana plants), $82 \%$ were classified as phylotype II (including all strains from banana). However, it was not possible to characterize most strains into sequevars, and, possibly, the banana strains belong to a not yet determined sequevar (PINHEIRO et al., 2011). This observation was also reported by Albuquerque et al. (2014) that described a new sequevar associated to Moko, named IIA-53. Strains from eucalypt plants were not grouped into known sequevars neither (FONSECA et al., 2014).

The prevalence of phylotype II in characterization studies of Brazilian strains of $R$. solanacearum confirms its correspondence to the American continent, as proposed by Fegan and Prior (2005). However, due to the exchange of plant material among continents, infection of host plants by strains from other regions of the world may occur, which may explain reports of phylotype I in the country (COELHO NETTO et al., 2003, 2004; SANTIAGO; LOPES; MIZUBUTI, 2012; GARCIA et al., 2013). 
Mistakenly, Pinheiro et al. (2011) published the characterization of four $R$. solanacearum strains (two from tomato plants from Guaraí-TO and Nova Friburgo-RJ, one from eggplants from Gurupi-TO, and one from bell pepper from Camocin S. FelixPE) as positive for phylotype III. However, the analysis of the amplicon size reveals correspondence to phylotype I, of $144 \mathrm{bp}$ (and not $91 \mathrm{bp}$ as mentioned by the authors). Thus, it was not the first report of phylotype III in the country, but again a confirmation of the occurrence of Asian strains in Brazil.

It is interesting to highlight that, in this review, some studies about the genetic variability of this bacterial population in Brazil report that the existence of diversity among strains oftentimes is correlated with its geographical origin (SILVEIRA et al., 2005; FONSECA et al., 2014), similarly to what was established for the classification into phylotypes. Therefore, the lower local bacterial variability allows disease control through the use of resistant cultivars recommended for each region of the country, although care should be taken against the dissemination of strains via propagation material.

The constant attempts to group $R$. solanacearum strains as they are identified open the opportunity for the suggestion of new classification schemes. One of them is based on the identification of virulence patterns in specific groups of hosts (LEBEAU et al., 2011). According to this classification, pathogenic profiles (pathoprofiles) would group the behavior of strains within a group of host plants of several species, while the pathotypes would group the strains according to their virulence within a single host species. Another classification suggests the division of $R$. solanacearum into new species (REMENANT et al., 2011; ALLEN et al., 2014; SAFNI et al., 2014). In the first putative proposal (REMENANT et al., 2011), only phylotype II strains would be classified as $R$. solanacearum, while phylotypes I and III would be included in the new species $R$. sequeirae and phylotype IV in $R$. haywardii. This proposal, however, was based on the genome analysis of only eight strains of the species complex $R$. solanacearum and did not include phenotypical differentiations associated to the new species. Taxonomic reviews proposed by Allen et al. (2014) (74 strains) and by Safni et al. (2014) (68 strains) are more similar to each other (Table 3). Both of them suggest the division into three species according to significant biological (phenotypical and pathogenic) differences and to genomic divergences. Thus, $R$. solanacearum would include strains corresponding to phylotype II, $R$. syzygii to phylotype IV, and a new species would include strains from phylotypes I and III: $R$. sequeirae sp. nov. (ALLEN et al., 2014) and $R$. pseudosolanacearum sp. nov. (SAFNI et al., 2014). The authors also divide the species $R$. syzygii into three distinct groups (Table 3). Such propositions have not been adopted by scientific community yet, and there are no studies in Brazil reporting these classification schemes.

Table 3. Taxonomic reviews proposed for the species complex Ralstonia solanacearum.

\begin{tabular}{|c|c|c|}
\hline \multirow{2}{*}{$\begin{array}{l}\text { Current classification } \\
\text { (FEGAN; PRIOR, 2005) }\end{array}$} & \multicolumn{2}{|c|}{ Proposed taxon } \\
\hline & ALLEN et al. (2014) & SAFNI et al. (2014) \\
\hline $\begin{array}{l}\text { Ralstonia solanacearum } \\
\text { (Phylotype II) }\end{array}$ & Ralstonia solanacearum & Ralstonia solanacearum \\
\hline $\begin{array}{l}\text { Ralstonia solanacearum } \\
\text { (Phylotype I) }\end{array}$ & Ralstonia sequei & $\begin{array}{l}\text { Ralstonia pseudosolanacearum sp. } \\
\text { nov. }\end{array}$ \\
\hline $\begin{array}{l}\text { Ralstonia solanacearum } \\
\text { (Phylotype III) }\end{array}$ & Ralstonia sequeirae sp. nov. & $\begin{array}{l}\text { Ralstonia pseudosolanacearum sp. } \\
\text { nov. }\end{array}$ \\
\hline $\begin{array}{l}\text { Ralstonia solanacearum } \\
\text { (Phylotype IV) }\end{array}$ & $\begin{array}{l}\text { Ralstonia syzygii } \\
\text { haywardii subsp. nov. }\end{array}$ & $\begin{array}{l}\text { Ralstonia } \quad \text { syzygii } \\
\text { indonesiensis } \\
\text { subsp. nov. }\end{array}$ \\
\hline $\begin{array}{l}\text { Ralstonia syzygii } \\
\text { (Phylotype IV) }\end{array}$ & Ralstonia syzygii subsp. syzygii & $\begin{array}{l}\text { Ralstonia syzygii subsp. syzygii } \\
\text { comb. nov. }\end{array}$ \\
\hline $\begin{array}{l}\text { BDB (Blood Disease Bacterium) } \\
\text { (Phylotype IV) }\end{array}$ & $\begin{array}{l}\text { Ralstonia syzygii } \\
\text { celebensis subsp. nov. }\end{array}$ & $\begin{array}{l}\text { Ralstonia } \quad \text { syzygii } \\
\text { celebesensis subsp. nov. }\end{array}$ \\
\hline
\end{tabular}

\section{CONCLUSIONS}

Studies about the occurrence and diversity of Ralstonia solanacearum provide a more consistent idea about the composition of prevailing populations in several agricultural areas of Brazil. Moreover, proper identification of bacteria is fundamental for better comprehension of pathogen ecology and etiology, as well as an aid for the 
establishment of control measures, including the use of resistant cultivars.

Success on disease management depends on the knowledge of which biovar, phylotype and sequevar of the species complex Ralstonia is present in the cropland. Such situation is due to differences among strains, especially in aspects related to aggressiveness, survival, and latency.

Research results compiled from literature report a wide distribution of the bacterium in Brazil, with prevalence of $\mathrm{R} 3 \mathrm{Bv} 2$ in potato in the South, general distribution of R1Bv1, R1Bv3 in the warmer regions of North, Northeast and Midwest, and the occurrence of biovar 2T out of the Amazon Basin. Prevalence of a certain biovar, besides soil and climate characteristics, is due to the cultivated vegetable species in that region. Also, greater bacterial population variability has been observed between locations, suggesting certain homogeneity within the regions where disease occurs. As the studies expand with new and representative strains of $R$. solanacearum, better positioning will be done on the pathogenic and molecular variability of the bacterium, bringing greater knowledge on epidemiological and ecological aspects needed for the proposition of control measures.

From this review, it was observed a paucity of records on the origin of vegetable material (mostly when dealing with species propagated by seedlings), the probable use of noncertified seedpotato, and the need for tests to detect the bacterium in soil, water, and plants with latent infections. Such scarcity of information, coupled to possible incorrect pathogen identification, limits epidemiological studies of bacterial wilt in Brazil.

\section{ACKNOWLEDGEMENTS}

To the Coordination of Higher Education Professionals Support (CAPES-Brazil) and the Research Foundation of the State of Minas Gerais (FAPEMIG) for the financial support.

RESUMO: Ralstonia solanacearum é uma bactéria gram-negativa habitante do solo capaz de infectar centenas de espécies vegetais distribuídas em mais de 50 famílias botânicas, onde causa a murcha-bacteriana, exceto na bananeira, na qual recebe o nome de Moko. Destaca-se entre outras bactérias fitopatogênicas pela sua alta plasticidade fenotípica e genotípica, característica que contribui sobremaneira para dificultar o controle da doença. Nesse contexto, levantamentos frequentes e necessários são conduzidos na tentativa de caracterizar isolados de $R$. solanacearum prevalentes em cada região onde a doença tem sido relatada. No Brasil, o conhecimento sobre a ocorrência e a variabilidade de $R$. solanacearum está fragmentado e, em alguns casos, baseado em estudos inconclusivos pelo uso de amostras de isolados pouco representativas de uma região. A necessidade de agrupar essas informações norteou a presente revisão de literatura. A ocorrência da bactéria nos Estados brasileiros e as possíveis causas de sua disseminação são apresentadas, com ênfase nos estudos da variabilidade genética das populações de $R$. solanacearum no país de acordo com o atual esquema de classificação da bactéria. Os resultados de pesquisa compilados da literatura reportam ampla distribuição da bactéria no Brasil e grande variabilidade de suas populações entre locais. Em parte devido à dificuldade de detectar pequenos números de células bacterianas em amostras, nota-se escassez de informações sobre a origem do inóculo em determinadas regiões, bem como a necessidade de detectar a presença do patógeno em plantas assintomáticas, em tubérculos de batata com infecções latentes, no solo e na água, que são as principais causas da disseminação da bactéria para áreas sem histórico da doença.

PALAVRAS-CHAVE: Murcha-bacteriana. Filotipos. Diversidade genética. Caracterização fenotípica.

\section{REFERENCES}

AKIBA, F.; KIMURA, O.; PIMENTEL, J. P.; RIBEIRO; R. L. D.; ROBBS, C. F. "Murcha Bacteriana" do feijão-vagem: doença nova para o Brasil. Fitopatologia Brasileira, Brasília, v. 5(Supl.), p. 379, 1980.

ALBUQUERQUE, G. M. R.; SANTOS, L. A.; FÉLIX, K. C. S.; ROLLEMBERG, C. L.; SILVA, A. M.; SOUZA, E. B.; CELLIER, G.; PRIOR, P.; MARIANO, R. L. R. Moko disease-causing strains of Ralstonia solanacearum from Brazil extend known diversity in paraphyletic phylotype II. Phytopathology, Saint Paul, v. 104, n. 11, p. 1175-1182, 2014. http://dx.doi.org/10.1094/PHYTO-12-13-0334-R

ALFENAS, A. C.; MAFIA, R. G.; SARTÓRIO, R. C.; BINOTI, D. H. B.; SILVA, R. R.; LAU, D.; VANETTI, C. A. Ralstonia solanacearum em viveiros clonais de eucalipto no Brasil. Fitopatologia Brasileira, Brasília, v. 31, n. 4, p. 357-366, 2006. http://dx.doi.org/10.1590/S0100-41582006000400005 
ALLEN, C.; AILLOUD, F.; REMENANT, B.; SANCHEZ, B.; DALSING, B.; BULL, C. T.; PRIOR, P. Division of the plant pathogen Ralstonia solanacearum into three species: $R$. solanacearum, $R$. sequeirae sp. nov., and $R$. syzygii. In: INTERNATIONAL CONFERENCE ON PLANT PATHOGENIC BACTERIA, 13., 2014, Shanghai, China. Proceedings... Shanghai, 2014.

ALMEIDA, I. M. G.; DESTÉFANO, S. A. L.; RODRIGUES NETO, J.; MALAVOLTA JÚNIOR, V.A. Southern bacterial wilt of geranium caused by Ralstonia solanacearum biovar 2/race 3 in Brazil. Revista Agricultura, v. 78, n. 1, p. 49-56, 2003.

ANDRADE, F. W. R.; AMORIM, E. P. R.; ELOY, A. P.; RUFINO, M. J. Ocorrência de doenças em bananeiras no Estado de Alagoas. Summa Phytopathologica, Jaguariúna, v. 35, n. 4, p. 305-309, 2009. http://dx.doi.org/10.1590/S0100-54052009000400008

ASSIS, S. M. P.; OLIVEIRA, I. S.; COVELLO, V. N.; REHN, K. G.; MARIANO, R. L. R. Bacterial wilt of Heliconia in Pernambuco, Brazil: first report and detection by PCR in soil and rhizomes. In: ALLEN, C.; PRIOR, P.; HAYWARD, A. C. (Ed.). Bacterial wilt: the disease and the Ralstonia solanacearum species complex. Saint Paul: American Phytopathological Society Press, 2005. p. 423-430.

AUER, C. G.; SANTOS, A. F.; RODRIGUES NETO, J. Ocorrência de murcha bacteriana em plantios de Eucalyptus grandis no Estado de Santa Catarina. Tropical Plant Pathology, v. 33(Supl.), p. 370, 2008.

BOUDAZIN, G.; LE ROUX, A. C.; JOSI, K.; LABARRE, P.; JOUAN, B. Design of division specific primers of Ralstonia solanacearum and application to the identification of European isolates. European Journal of Plant Pathology, v. 105, p. 373-380, 1999. http://dx.doi.org/10.1023/A:1008763111230

BRINGEL, J. M. M.; TAKATSU, A.; UESUGI, C. H. Colonização radicular de plantas cultivadas por Ralstonia solanacearum biovares 1, 2 e 3. Scientia Agricola, v. 58, n. 3, p. 497-500, 2001. http://dx.doi.org/10.1590/S0103-90162001000300010

BUDDENHAGEN, I. W. Bacterial wilt revisited. In: PERSLEY, G. (Ed.). Bacterial wilt disease in Asia and the South Pacific. Canberra: ACIAR, 1986. p. 126-143.

BUDDENHAGEN, I. W.; KELMAN, A. Biological and physiological aspects of bacterial wilt caused by Pseudomonas solanacearum. Annual Review of Phytopathology, v. 2, p. 203-230, 1964. http://dx.doi.org/10.1146/annurev.py.02.090164.001223

BUDDENHAGEN, I. W.; SEQUEIRA, L.; KELMAN, A. Designations of races of Pseudomonas solanacearum. Phytopathology, Saint Paul, v. 52(Supl.), p. 726, 1962.

CELLIER, G.; PRIOR, P. Deciphering phenotypic diversity of Ralstonia solanacearum strains pathogenic to potato. Phytopathology, Saint Paul, v. 100, n. 11, p. 1250-1261, 2010. http://dx.doi.org/10.1094/PHYTO-02$10-0059$

COELHO NETTO, R. A.; PEREIRA, B. G.; NODA, H.; BOHER, B. Caracterização de isolados de Ralstonia solanacearum obtidos de tomateiros em várzea e em terra firme, no Estado do Amazonas. Fitopatologia Brasileira, Brasília,v. 28, n. 4, p. 362-366, 2003. http://dx.doi.org/10.1590/S0100-41582003000400003

COELHO NETTO, R. A.; PEREIRA, B. G.; NODA, H.; BOHER, B. Murcha bacteriana no Estado do Amazonas, Brasil. Fitopatologia Brasileira, Brasília, v. 29, p. 21-27, 2004. http://dx.doi.org/10.1590/S010041582004000100004

COENYE, T.; VANDAMME, P. Simple sequences repeats and compositional bias in the bipartide Ralstonia solanacearum GMI1000 genome. BMC Genomics, v. 4, n. 10, e1471-2164-4-10, 2003. 
CONABAN - Confederação Nacional dos Bananicultores. Ponderações técnicas sobre a importação de bananas do Equador. São Paulo: Conaban, 2012. 46p.

COSTA, S. B.; FERREIRA, M. A. S. V.; LOPES, C. A. Diversidade patogênica e molecular de Ralstonia solanacearum da região amazônica brasileira. Fitopatologia Brasileira, Brasília,v. 32, n. 4, p. 285-294, 2007. http://dx.doi.org/10.1590/S0100-41582007000400002

DIANESE, J. C.; TAKATSU, A. Pseudomonas solanacearum biovar 1 isolada de eucalipto em Monte Dourado, Estado do Pará. Fitopatologia Brasileira, Brasília,v. 10(Supl.), p. 362, 1985.

DRISTIG, M. C. G.; DIANESE, J. C.; TAKATSU, A. Characterization of Pseudomonas solanacearum isolated from eucalyptus. Fitopatologia Brasileira, Brasília, v. 13(Supl.), p. 106, 1988.

DUARTE, V.; DALBOSCO, M.; TASSA, S. O. M. Identificação de isolados de Ralstonia solanacearum provenientes de plantas de fumo da Bahia e do Rio Grande do Sul. Fitopatologia Brasileira, Brasília,v. 28(Supl.), p. 239, 2003.

ELPHINSTONE, J. G.; HENNESSY, J.; WILSON, J. K.; STEAD, D. E. Sensitivity of different methods for the detection of Ralstonia solanacearum in potato tuber extracts. Bulletin OEPP/EPPO, v. 26, p. 663-678, 1996.

FEGAN, M.; PRIOR, P. How complex is the "Ralstonia solanacearum species complex". In: ALLEN, C.; PRIOR, P.; HAYWARD, A. C. (Ed.). Bacterial wilt: the disease and the Ralstonia solanacearum species complex. Saint Paul: American Phytopathological Society Press, 2005. p. 449-461.

FEGAN, M.; HOLOWAY, G.; HAYWARD, A. C.; TIMMIS, J. Development of a diagnostic test based on the polymerase chain reaction (PCR) to identify strains of Ralstonia solanacearum exhibiting the biovar 2 genotype. In: PRIOR, P.; ALLEN, C.; ELPHINSTONE, J. G. (Ed.). Bacterial wilt disease: molecular and ecological aspects. Heidelberg, Germany: Springer Verlag, 1998. p. 34-43. http://dx.doi.org/10.1007/978-3662-03592-4_5

FELIX, K. C. S.; SOUZA, E. B.; MICHEREFF, S. J.; MARIANO, R. L. R. Survival of Ralstonia solanacearum in infected tissues of Capsicum annuum and in soils of the state of Pernambuco, Brazil. Phytoparasitica, v. 40, p. 53-62, 2012. http://dx.doi.org/10.1007/s12600-011-0200-6

FONSECA, N. R.; GUIMARÃES, L. M. S.; HERMENEGILDO, P. S.; TEIXEIRA, R. U.; LOPES, C. A.; ALFENAS, A. C. Molecular characterization of Ralstonia solanacearum infecting Eucalyptus spp. in Brazil. Forest Pathology, v. 44, n. 2, p. 107-116, 2014. http://dx.doi.org/10.1111/efp.12073

FREIRE, F. C. O.; CARDOSO, J. E.; VIANA, F. M. P. Doenças de fruteiras tropicais de interesse agroindustrial. Brasília: Embrapa Informação Tecnológica, 2003. 687p.

FRENCH, E. R.; ALEY, P.; TORRES, E.; NYDEGGER, U. Diversity of Pseudomonas solanacearum in Peru and Brazil. In: HARTMAN, G. L.; HAYWARD, A. C. (Ed.). Bacterial wilt. Canberra: ACIAR Proceedings, 1993. p. 70-77.

GARCIA, A. L.; LIMA, W. G.; SOUZA, E. B.; MICHEREFF, S. J.; MARIANO, R. L. R. Characterization of Ralstonia solanacearum causing bacterial wilt in bell pepper in the state of Pernambuco, Brazil. Journal of Plant Pathology, v. 95, n. 2, p. 237-245, 2013.

GONÇALVES, R. D. Murcha da dália e da berinjela. O Biológico, v. 3, n. 1, p. 27-28, 1937. 
GUIDOT, A.; ELBAZ, M.; CARRÈRE, S.; SIRI, M. I.; PIANZZOLA, M. J.; PRIOR, P.; BOUCHER, C. Specific genes from the potato brown rot strains of Ralstonia solanacearum and their potential use for strain detection. Phytopathology, Saint Paul, v. 99, p. 1105-1112, 2009. http://dx.doi.org/10.1094/PHYTO-99-91105

HAYWARD, A. C. Biology and epidemiology of bacterial wilt caused by Pseudomonas solanacearum. Annual Review of Phytopathology, v. 29, p. 65-87, 1991. http://dx.doi.org/10.1146/annurev.py.29.090191.000433

HAYWARD, A. C. The hosts of Pseudomonas solanacearum. In: HAYWARD, A. C.; HARTMAN, G. L. (Ed.). Bacterial wilt: the disease and its causative agent, Pseudomonas solanacearum. Wallingford: CAB International, 1994. p. 9-24.

HAYWARD, A. C.; FEGAN, M. The Ralstonia solanacearum species complex: genetic diversity and physiology of the pathogen and ecology of bacterial wilt. Phytopathology, Saint Paul, v. 94, p. 121, 2004.

IVEY, M. L. L.; GARDNER, B. B. M.; OPINA, N.; MILLER, S. A. Diversity and geographic distribution of Ralstonia solanacearum from eggplant in Philippines. Phytopathology, Saint Paul, v. 97, p. 1467-1475, 2007. http://dx.doi.org/10.1094/PHYTO-97-11-1467

JAUNET, T. X.; WANG, J. F. Variation in genotype and aggressiveness of Ralstonia solanacearum race 1 isolated from tomato in Taiwan. Phytopathology, Saint Paul, v. 89, p. 320-327, 1999. http://dx.doi.org/10.1094/PHYTO.1999.89.4.320

JI, P.; ALLEN, C.; SANCHEZ-PEREZ, A.; YAO, J.; ELPHINSTONE, J. G.; JONES, J. B.; MOMOL, M. T. New diversity of Ralstonia solanacearum strains associated with vegetable and ornamental crops in Florida. Plant Disease, v. 91, n. 2, p. 195-203, 2007. http://dx.doi.org/10.1094/PDIS-91-2-0195

KELMAN, A. The bacterial wilt caused by Pseudomonas solanacearum: a literature review and bibliography. Raleigh, USA: North Carolina Agricultural Experiment Station, Technical Bulletin. v. 99, 1953. $194 \mathrm{p}$.

KUMAR, A.; SARMA, Y. R.; ANANDARAJ, M. Evaluation of genetic diversity of Ralstonia solanacearum causing bacterial wilt of ginger using REP-PCR and PCR-RFLP. Current Science, v. 87, p. 1555-1561, 2004.

LEBEAU, A.; DAUNAY, M. C.; FRARY, A.; PALLOIX, A.; WANG, J. F.; DINTINGER, J.; CHIROLEU, F.; WICKER, E.; PRIOR, P. Bacterial wilt resistance in tomato, pepper, and eggplant: genetic resources respond to diverse strains in the Ralstonia solanacearum species complex. Phytopathology, Saint Paul, v. 101, p. 154165, 2011. http://dx.doi.org/10.1094/PHYTO-02-10-0048

LIMA, H. E.; RÊGO, E. R.; CAVALCANTE, G. P.; RÊGO, M. M.; COTA, L. V. Reação em campo à murcha bacteriana de cultivares de tomate em Roraima. Horticultura Brasileira, Brasília, v. 28, n. 2, p. 227-231, 2010. http://dx.doi.org/10.1590/S0102-05362010000200016

LIMA NETO, A. F.; ÁLVAREZ, E. R.; BOITEUX, L. S.; LOPES, C. A. Detección de Ralstonia solanacearum biovar 3 en el Estado de Tocantins y diagnóstico mediante PCR y técnicas enzimáticas. Fitosanidad, v. 13(Supl.), p. 69, 2009.

LOPES, C. A. Murchadeira da batata. Itapetininga: ABBA / Brasília: Embrapa Hortaliças, 2005. 68p.

LOPES, C. A.; POLTRONIERI, L. S.; QUEZADO-SOARES, A. M.; TRINDADE, D. R.; ALBUQUERQUE, F. C. Maracujazeiro, mais um hospedeiro de Ralstonia solanacearum. Summa Phytopathologica, Jaguariúna, v. 25(Supl.), p. 26, 1999. 
LOPES, C. A.; ROSSATO, M.; BOITEUX, L. S. Murcha-bacteriana: nova ameaça à cafeicultura brasileira? In: SIMPÓSIO DE PESQUISA DOS CAFÉS DO BRASIL, 6., 2009, Vitória, ES. Proceedings... Vitória, 2009. p. $1-6$.

LOPES, C. A.; NAZARENO, N. R. X.; FURIATTI, R. S. Prevalência, mas não exclusividade, da raça 3 de Pseudomonas solanacearum em batata no Estado do Paraná. Fitopatologia Brasileira, Brasília,v. 18(Supl.), p. 312, 1993.

LOPES, C. A.; CARVALHO, S. I. C.; BOITEUX, L. S. Search for resistance to bacterial wilt in a Brazilian Capsicum germplasm collection. In: ALLEN, C.; PRIOR, P.; HAYWARD, A. C. (Ed.). Bacterial wilt: the disease and the Ralstonia solanacearum species complex. Saint Paul: American Phytopathological Society Press, 2005. p. 247-251.

MACIEL, J. L. N.; DUARTE, V.; SILVEIRA, J. R. P. Densidade populacional de Ralstonia solanacearum em cultivares de batata a campo. Ciência Rural, v. 34, p. 19-24, 2004. http://dx.doi.org/10.1590/S010384782004000100004

MACIEL, J. L. N.; SILVEIRA, J. R. P.; VAN DER SAND, S. T.; DUARTE, V. Frequência de biovares de Ralstonia solanacearum em diferentes cultivares e épocas de cultivo de batata no Rio Grande do Sul. Fitopatologia Brasileira, Brasília,v. 26, n. 4, p. 741-744, 2001. http://dx.doi.org/10.1590/S010041582001000400009

MAFIA, R. G.; ALFENAS, A. C.; PENCHEL FILHO, R. M.; FERREIRA, M. A.; ALFENAS, R. F. Murchabacteriana: disseminação do patógeno e efeitos da doença sobre a clonagem do eucalipto. Revista Árvore, v. 36, n. 4, p. 593-602, 2012. http://dx.doi.org/10.1590/S0100-67622012000400002

MALAVOLTA JÚNIOR, V. A.; BERIAM, L. O. S.; ALMEIDA, I. M. G.; RODRIGUES NETO, J.; ROBBS, C. F. Bactérias fitopatogênicas assinaladas no Brasil: uma atualização. Summa Phytopathologica, Jaguariúna, v. 34(Special Suplement), p. 9-87, 2008.

MAPA - Ministério da Agricultura, Pecuária e Abastecimento. Instrução Normativa No 59 de 18/12/2013. Available at: http://sistemasweb.agricultura.gov.br/sislegis/action/detalhaAto.do?method=consultarLegislacaoFederal. Accessed: 05 Jun 2014.

MARIANO, R. L. R.; CABRAL, G. B.; SILVA, M. S. S. G. Levantamento das fitobacterioses do Estado de Pernambuco em 1987. Fitopatologia Brasileira, Brasília, v. 13(Supl.), p. 130, 1988

MARIANO, R. L. R.; MELO, R. A. G.; HOLANDA, V. T.; CABRAL, G. B.; SILVA, M. S. S. G. Levantamento das fitobacterioses do Estado de Pernambuco no biênio 1987-1988. Fitopatologia Brasileira, Brasília,v. 14(Supl.), p. 158, 1989. . http://dx.doi.org/10.1007/978-3-662-03592-4_59

MARIANO, R. L. R.; SILVEIRA, N. S. S.; MICHEREFF, S. J. Bacterial wilt in Brazil: current status and control methods. In: PRIOR, P.; ALLEN, C.; ELPHINSTONE, J. G. (Ed.). Bacterial wilt disease: molecular and ecological aspects. Berlin: Springer, 1998. p. 386-393.

MARQUES, E.; UESUGI, C. H.; FERREIRA, M. A. S. V.; REZENDE, D. V. Characterization of isolates of Ralstonia solanacearum biovar 2, pathogenic to Eucalyptus "urograndis" hybrids. Tropical Plant Pathology, Brasília, v. 37, n. 6, p. 399-408, 2012. http://dx.doi.org/10.1590/S1982-56762012000600004

MARTINS, O. M.; TAKATSU, A.; REIFSCHNEIDER, F. J. B. Virulência de biovares I e III de Pseudomonas solanacearum ao tomateiro. Fitopatologia Brasileira, Brasília, v. 13, n. 3, p. 249-252, 1988.

OPINA, N.; TAVNER, F.; HOLLOWAY, G.; WANG, J. F.; LI, T. H.; MAGHIRANG, R.; FEGAN, M.; HAYWARD, A. C.; KRISHNAPILLAI, V.; HONG, W. F.; HOLLOWAY, B. W.; TIMMIS, J. N. A novel 
method for development of species and strain-specific DNA probes and PCR primers for identifying Burkholderia solanacearum (formerly Pseudomonas solanacearum). Asia-Pacific Journal of Molecular Biology and Biotechnology, v. 5, p. 19-33, 1997.

PARENTE, P. M. G.; TAKATSU, A.; LOPES, C. A. Ocorrência de Pseudomonas solanacearum em pepino. Horticultura Brasileira, Brasília, v. 6, p. 26-27, 1988.

PASTRIK, K. H.; MAISS, E. Detection of Ralstonia solanacearum in potato tubers by polymerase chain reaction. Journal of Phytopathology, v. 148, p. 619-626, 2000. http://dx.doi.org/10.1046/j.1439-

0434.2000.00567.x

http://dx.doi.org/10.1111/j.1439-0434.2000.00567.x

PEREZ, A. S.; MEJIA, L.; FEGAN, M.; ALLEN, C. Diversity and distribution of Ralstonia solanacearum strains in Guatemala and rare occurrence of tomato fruit infection. Plant Pathology, v. 57, n. 2, p. 320-331, 2008. http://dx.doi.org/10.1111/j.1365-3059.2007.01769.x

PINHEIRO, C. R.; AMORIM, J. A. E.; DINIZ, L. E. C.; SILVA, A. M. F.; TALAMINI, V.; SOUZA JÚNIOR, M. T. Diversidade genética de isolados de Ralstonia solanacearum e caracterização molecular quanto a filotipos e sequevares. Pesquisa Agropecuária Brasileira, v.46, n.6, p.593-602, 2011. http://dx.doi.org/10.1590/S0100-204X2011000600004

POUSSIER, S.; LUISETTI, J. Specific detection of biovars of Ralstonia solanacearum in plant tissue by nested PCR. European Journal of Plant Pathology, v. 106, p. 255-265, 2000.

http://dx.doi.org/10.1023/A:1008742609761

POUSSIER, S.; VANDEWALLE, P.; LUISETTI, J. Genetic diversity of African and worldwide strains of Ralstonia solanacearum as determined by PCR-restriction fragment length polymorphism analysis of the hrp gene region. Applied and Environmental Microbiology, v. 65, p. 2184-2194, 1999.

REMENANT, B.; DE CAMBIAIRE, J. C.; CELLIER, G.; JACOBS, J. M.; MANGENOT, S. Ralstonia syzygii, the blood disease bacterium and some Asian $R$. solanacearum strains form a single genomic species despite divergent lifestyles. PLoS ONE, v. 6, e24356, 2011. http://dx.doi.org/10.1371/journal.pone.0024356

REMENANT, B.; COUPAT-GOUTALAND, B.; GUIDOT, A.; CELLIER, G.; WICKER, E.; ALLEN, C.; FEGAN, M.; PRUVOST, O.; ELBAZ, M.; CALTEAU, A.; SALVIGNOL, G.; MORNICO, D.; MANGENOT, S.; BARBE, V.; MÉDIGUE, C.; PRIOR, P. Genomes of three tomato pathogens within the Ralstonia solanacearum species complex reveal significant evolutionary divergence. BMC Genomics, v. 11, p. 379, 2010. http://dx.doi.org/10.1186/1471-2164-11-379

ROBBS, C. F.; CRUZ, A. P.; RODRIGUES NETO, J. Algumas estratégias no controle da murcha bacteriana (Pseudomonas solanacearum) em eucaliptos. Jaguariúna: Embrapa. n.3, 1988. 4p.

RODRIGUES, L. M. R.; DESTÉFANO, S. A. L.; DINIZ, M. C. T.; COMPARONI, R.; RODRIGUES NETO, J. Pathogenicity of Brazilian strains of Ralstonia solanacearum in Strelitzia reginae seedlings. Tropical Plant Pathology, Brasília, v. 36, n. 6, p. 409-413, 2011. http://dx.doi.org/10.1590/S1982-56762011000600011

ROSSATO, M. Caracterização molecular e avaliação da patogenicidade em gerânio de isolados brasileiros da biovar 2 de Ralstonia solanacearum. 2012. 46f. M.Sc. Dissertation, Universidade Federal de Viçosa, Viçosa, 2012. 
SAFNI, I.; CLEENWERCK, I.; DE VOS, P.; FEGAN, M.; SLY, L.; KAPPLER, U. Polyphasic taxonomic revision of the Ralstonia solanacearum species complex: proposal to emend the descriptions of $R$. solanacearum and $R$. syzygii and reclassify current $R$. syzygii strains as Ralstonia syzygii subsp. syzygii, $R$. solanacearum phylotype IV strains as Ralstonia syzygii subsp. indonesiensis subsp. nov., banana blood disease bacterium strains as Ralstonia syzygii subsp. celebesensis subsp. nov. and $R$. solanacearum phylotypes I and III strains as Ralstonia pseudosolanacearum sp. nov. International Journal of Systematic and Evolutionary Microbiology, v. 64, p. 3087-3103, 2014. http://dx.doi.org/10.1099/ijs.0.066712-0

SALANOUBAT, M.; GENIN, S.; ARTIGUENAVE, F.; GOUZY, J.; MANGENOT, S.; ARLAT, M.; BILLAULT, A.; BROTTIER, P.; CAMUS, J. C.; CATTOLICO, L.; CHANDLER, M.; CHOISNE, N.; CLAUDEL-RENARD, C.; CUNNAC, S.; DEMANGE, N.; GASPIN, C.; LAVIE, M.; MOISAN, A.; ROBERT, C.; SAURIN, W.; SCHIEX, T.; SIGUIER, P.; THÉBAULT, P.; WHALEN, M.; WINCKER, P.; LEVY, M.; WEISSENBACH, J.; BOUCHER, C. A. Genome sequence of the plant pathogen Ralstonia solanacearum. Nature, v. 415, p. 497-502, 2002. http://dx.doi.org/10.1038/415497a

SANTANA, B. G.; LOPES, C. A.; ALVAREZ, E.; BARRETO, C. C.; ALLEN, C.; QUIRINO, B. F. Diversity of Brazilian biovar 2 strains of Ralstonia solanacearum. Journal of General Plant Pathology, v. 78, n. 3, p. 190-200, 2012. http://dx.doi.org/10.1007/s10327-012-0369-7

SANTIAGO, T. R.; LOPES, C. A.; MIZUBUTI, E. S. G. Genetic characterization of Ralstonia solanacearum causing bacterial wilt in Brazil. Tropical Plant Pathology, Brasília, v. 38(Supl.), p. 587, 2012.

SEAL, S. E.; JACKSON, L. A.; YOUNG, J. C. P. W.; DANIELS, M. J. Diferentiation of Pseudomonas solanacearum, Pseudomona syzgii, Pseudomona pickettii and the blood disease bacterium by partial 16S rRNA sequencing: construction of oligonucleotide primers for sensitive detection by polymerase chain reaction.

Journal of General Microbiology, v. 139, p. 1587-1594, 1993. http://dx.doi.org/10.1099/00221287-139-71587

SILVEIRA, J. R. P.; DUARTE, V.; MORAES, M. G. Ocorrência das biovares 1 e 2 de Ralstonia solanacearum em lavouras de batata no Estado do Rio Grande do Sul. Fitopatologia Brasileira, Brasília,v. 27, n. 5, p. 450453, 2002. http://dx.doi.org/10.1590/S0100-41582002000500002

SILVEIRA, J. R. P.; DUARTE, V.; MORAES, M. G.; OLIVEIRA, A. M. R.; BARNI, V.; MACIEL, J. L. N. Caracterização de estirpes de Ralstonia solanacearum isoladas de plantas de batata com murcha bacteriana, por PCR-rep e RAPD. Fitopatologia Brasileira, Brasília,v. 30, n. 6, p. 615-622, 2005.

http://dx.doi.org/10.1590/S0100-41582005000600008

SILVEIRA, J. R. P.; RUPRECHT, V. C.; SILVA, M. M.; LISBOA, B. B.; VARGAS, L. K.; OLIVEIRA, A. M. R. Predominância da biovar 1 de Ralstonia solanacearum em olerícolas cultivadas no Estado do Rio Grande do Sul. Pesquisa Agropecuária Gaúcha, v. 12, p. 31-36, 2006.

SINIGAGLIA, C.; LOPES, M. E. B. M.; ALMEIDA, I. M. G.; RODRIGUES NETO, J. Bacterial wilt of summer squash (Cucurbita pepo) caused by Ralstonia solanacearum in the State of São Paulo, Brazil. Summa Phytopathologica, Jaguariúna, v. 27, p. 251-253, 2001.

SMITH, E. F. A bacterial disease of tomato, pepper, eggplant and Irish potato (Bacillus solanacearum nov. sp.). United States Department of Agriculture: Division of Vegetable Physiology and Pathology, Bulletin, v. 12, p. $1-28,1896$.

SMITH, E. F. Bacteria in relation to plant disease. Washington: Carnegie Institution, 1914. 309p.

SOARES, D. J.; ROCHA, G. M. G.; NÓBREGA, M. B. M.; COSTA, M. N. Ocorrência da murcha-bacteriana em mamoneira na microrregião de Areia-PB. In: CONGRESSO BRASILEIRO DE MAMONA, 4., SIMPÓSIO INTERNACIONAL DE OLEAGINOSAS ENERGÉTICAS, 1., 2010, João Pessoa, PB. Proceedings... João Pessoa, 2010. p. 1020-1025. 
SUDO, S.; OLIVEIRA, G. H. N.; PEREIRA, A. C. Eucalipto (Eucalyptus sp.) e Bracatinga (Mimosa scabrella Penth), novos hospedeiros de Pseudomonas solanacearum E.F. Smith. Fitopatologia Brasileira, Brasília,v. 8(Supl.), p. 631, 1983.

TAKATSU, A.; LOPES, C. A. Murcha-bacteriana em hortaliças: avanços científicos e perspectivas de controle. Horticultura Brasileira, Brasília, v.15(Supl.), p. 170-177, 1997.

TAKATSU, A.; SILVA, C. B.; REIFSCHNEIDER, F. J. B. Variabilidade e distribuição de Pseudomonas solanacearum de solanáceas nas diferentes regiões do Brasil. Fitopatologia Brasileira, Brasília, v. 9, p. 387, 1984.

TALAMINI, V.; SILVA, A. M. F.; ALMEIDA, N. A.; MORAES, A. C.; WARWICK, D. R. N.; NASCIMENTO, M. A. A.; DEVI, C. K. Situação do moko da bananeira no Estado de Sergipe. Aracaju: Embrapa Tabuleiros Costeiros. n. 159, 2010. 16p.

TEBALDI, N. D.; LEITE, L. N.; MARQUES, J. M.; FURLANETO, M. C. A.; MOTA, L. C. B. M. Occurrence of Ralstonia solanaecarum on olive tree in Brazil. Summa Phytopathologica, Jaguariúna, v. 40, n. 2, p. 185, 2014. http://dx.doi.org/10.1590/0100-5405/1983

TOKESHI, H.; DUARTE, M. R. L. Moko da bananeira no Território Federal do Amapá. Summa Phytopathologica, Jaguariúna, v. 2, n. 3, p. 224-229, 1976.

VIANA, F. C.; BERGER, I. J.; DUARTE, V. Caracterização de populações de Ralstonia solanacearum Smith em tabaco (Nicotiana tabacum L.) no Brasil. Tropical Plant Pathology, Brasília, v. 37, n. 2, p. 123-129, 2012.

VIEIRA JÚNIOR, J. R.; FERNANDES, C. F.; ANTUNES JÚNIOR, H.; SILVA, D. S. G.; LIMA, R. F.; FERNANDES NETO, A.; SILVA, R. B. Levantamento da ocorrência do moko-da-bananeira em Rondônia: primeira atualização. Porto Velho: Embrapa Rondônia. n. 361, 2010. 6p.

VILLA, J. E.; TSUCHIYA, K.; HORITA, M.; NATURAL, M.; OPINA, N.; HYAKUMACHI, M. Phylogenetic relationships of Ralstonia solanacearum species complex strains from Asia and other continents based on 16S rDNA, endoglucanase, and $h r p B$ gene sequences. Journal of General Plant Pathology, v. 71, n. 1, p. 39-46, 2005. http://dx.doi.org/10.1007/s10327-004-0156-1

VON PARSEVAL, M. Uma doença do fumo e da batata inglesa no município de Santa Cruz. Porto Alegre: Instituto Borges de Medeiros. Boletim 1, 1922. 15p.

WELLER, S. A.; ELPHINSTONE, J. G.; SMITH, N. C.; BOONHAM, N.; STEAD, D. E. Detection of Ralstonia solanacearum strains with a quantitative, multiplex, real-time, fluorogenic PCR (TaqMan) assay. Applied and Environmental Microbiology, v. 66, p. 2853-2858, 2000. http://dx.doi.org/10.1128/AEM.66.7.2853-2858.2000

XU, J.; PAN, Z. C.; PRIOR, P.; XU, J. S.; ZHANG, Z.; ZHANG, H.; ZHANG, L. Q.; HE, L. Y.; FENG, J. Genetic diversity of Ralstonia solanacearum strains from China. European Journal of Plant Pathology, v. 125, p. 641-653, 2009. http://dx.doi.org/10.1007/s10658-009-9512-5

YABUUCHI, E.; KOSAKO, Y.; OYIZU, H.; YANO, I.; HOTTA, H.; HASHIMOTO, Y.; EZAKI, T.; ARAKAWA, M. Proposal of Burkholderia gen. nov. and transfer of seven species of the genus Pseudomonas homology group II to the new genus, with the type species Burkholderia cepacia (Palleroni and Holmes, 1981) comb. nov. Microbiology and Immunology, v. 36, n. 12, p. 1251-1275, 1992.

http://dx.doi.org/10.1111/j.1348-0421.1992.tb02129.x 
YABUUCHI, E.; KOSAKO, Y.; YANO, I.; HOTTA, H.; NISHIUCHI, Y. Transfer of two Burkholderia and an Alcaligenes species to Ralstonia gen. nov.: proposal of Ralstonia pickettii (Ralston, Palleroni and Douderoff 1973) comb. nov., Ralstonia solanacearum (Smith 1896) comb. nov. \& Ralstonia eutropha (Davis 1969) comb. nov. Microbiology and Immunology, v. 39, n. 11, p. 897-904, 1995. http://dx.doi.org/10.1111/j.13480421.1995.tb03275.x

YABUUCHI, E.; KOSAKO, Y.; YANO, I.; HOTTA, H.; NISHIUCHI, Y. Validation of the publication of new names and new combinations previously effectively published outside the IJBS. International Journal of Systematic Bacteriology, v. 46, n. 2, p. 625-626, 1996. http://dx.doi.org/10.1099/00207713-46-2-625

YU, Q.; ALVAREZ, A. M.; MOORE, P. H.; ZEE, F.; KIM, M. S.; SILVA, A.; HEPPERLY, P. R.; MING, R. Molecular diversity of Ralstonia solanacearum isolated from ginger in Hawaii. Phytopathology, Saint Paul, v. 93, p. 1124-1130, 2003. http://dx.doi.org/10.1094/PHYTO.2003.93.9.1124

ZOCCOLI, D. M.; TOMITA, C. K.; UESUGI, C. H. Ocorrência de murcha bacteriana em helicônias e musácea ornamental no Distrito Federal. Tropical Plant Pathology, Brasília, v. 34, n. 1, p. 45-46, 2009.

http://dx.doi.org/10.1590/S1982-56762009000100008 